\title{
Manipulation of dietary conditions for maximal growth in mussels, Mytilus edulis, from the Marennes-Oléron Bay, France
}

\author{
Anthony J. S. Hawkins (1), Rowena F. M. Smith (1), \\ Serge Bougrier ${ }^{(2)}$, Brian L. Bayne ${ }^{(1)}$ and Maurice Héral (3) \\ (1) Plymouth Marine Laboratory, Natural Environment Research Council, West Hoe, Plymouth PI.1 3DH, \\ United Kingdom.E-mail: A.Hawkins@pml.ac.uk \\ (2) IFREMER-LABEIM, BP 133, 17390 La Tremblade, France. \\ (3) IFREMER, BP 5, 17137 L'Hmumeau, France.
}

Received March 22, 1996; accepted September 16, 1996.

Hawkins A.J.S., R.F.M. Smith, S. Bougrier, B.L. Bayne, M. Héral. Aquat. Living Resour., 1997, 10, 13-22.

\begin{abstract}
Results are presented from laboratory-based experiments in which we investigated short-term responses of Mytilus edulis L. to experimental changes in the amount and composition of suspended seston. Working with large quantities of cultured algae, we have studied feeding behaviour over ranges of food availability and quality that extend well beyond earlier limits. Findings confirm the ability of mussels to selectively reject inorganic particles as pseudofaeces prior to ingestion, thereby enriching the organic content of ingested matter by $30 \%$ more than the organic content of natural filtered seston. Our findings also establish acclimation both of selective and absorptive processes, indicating that the extent to which growth of $M$. edulis can be stimulated in the short-term will depend upon prior nutritional history. Present maximal growth of $14.8 \%$ dry soft tissue $\mathrm{d}^{-1}$ in a standard $M$. edulis of $1 \mathrm{~g}$ dry soft tissue was much higher than has previously been documented for any adult mussel. Maximal growth was achieved when natural seston that had been enriched to more than about $60 \%$ organic content with a mixture of algal monocultures was available at concentrations above about $11.5 \mathrm{mg}$ total particulates $\mathrm{I}^{-1}$. Neither ingestion rate nor net energy balance were improved with further increases in food availability, associated with regulatory reductions in the rate of water filtration (clearance rate) that maintained organic ingestion rate independent of increases in both the amount and organic content of available seston. These findings suggest that digestive processes had become saturated when organic ingestion reached about $6.5 \mathrm{mg}$ organics $\mathrm{g}^{-1}$ dry soft tissue $\mathrm{h}^{-1}$ in a standard $M$. edulis of $1 \mathrm{~g}$ dry soft tissue, representing as much as $20.6 \%$ of all soft tissue organic mass mussel ${ }^{-1} \mathrm{~d}^{-1}$. Such saturation of organic ingestion is consistent with previous conclusions based on comparative allometries showing that limitations to growth in $M$. edulis and other bivalves are associated with the rate of food processing.
\end{abstract}

Keywords: Mytilus edulis, feeding behaviour, regulation, maximum growth rate.

Manipulations des conditions alimentaires pour une croissance maximale chez la moule, Mytilus edulis, de Marennes-Oléron, France.

Résumé

Des expérimentations ont été réalisées en laboratoire pour déterminer les réponses à court terme de la moule Mytilus edulis soumise à des changements dans la quantité et la qualité de la nourriture. L'apport de fortes quantités d'algues phytoplanctoniques a permis d'étudier le comportement de la moule pour des conditions supérieures à celles décrites antérieurement. Les résultats confirment que la moule rejète préférentiellement les particules minérales dans les pseudofêces, induisant un enrichissement de $30 \%$ de la matière organique ingérée par rapport à la matière organique filtrée. Ainsi, l'acclimatation aux 
conditions nutritionnelles agit sur les phénomènes de sélection et d'absorption. La croissance de Mytilus edulis peut être stimulée à court terme en fonction de son passé nutritionnel. La croissance maximale obtenue, pour une charge sestonique de $11,5 \mathrm{mg} . \mathrm{l}^{-1}$ composée de $60 \%$ de matière organique, est de $14,8 \%$ de chair sèche ; calculée pour un animal standard de $1 \mathrm{~g}$ de chair sèche et par jour, cette croissance est nettement supérieure à celle décrite précédemment pour des moules adultes. Une augmentation de la concentration de la nourriture disponible n'engendre pas d'amélioration, ni de la quantité de matière organique ingérée, ni du bilan énergétique. En effet, ces fonctions physiologiques sont associées à des réductions compensatoires de la filtration de l'animal qui maintiennent l'ingestion de la matière organique indépendante d'une part, de la charge et d'autre part, du taux de matière organique du seston disponible. En conséquence, les processus digestifs atteindraient un seuil de saturation lorsque l'ingestion organique correspondrait à $6,5 \mathrm{mg}$ de matière organique par heure, pour une moule standard de $1 \mathrm{~g}$ de chair sèche ; ce qui représente près de $20,6 \%$ du poids de matière organique de la chair, par moule et par jour. Une telle saturation de l'ingestion organique est cohérente avec les conclusions antérieures basées sur des allométries comparatives, qui montrent que les limites de croissance chez $M$. edulis et d'autres bivalves sont associées aux taux d'utilisation de la nourriture.

Mots-clés : Mytilus edulis, comportement alimentaire, régulation, croissance.

\section{-INTRODUCTION}

Given high densities (Boromthanarat and DeslousPaoli, 1988), mussels are the most active consumer per unit surface area in the Bay of Marennes-Oléron (Deslous-Paoli et al., 1990). This means that the feeding and growth of mussels must be considered during local environmental management, including estimation of the trophic capacity for culture of filter-feeding shellfish.

The primary purpose of work described here was to help establish parameters required for the successful modelling of growth in mussels (Mytilus edulis) from Marennes-Oléron. It is increasingly appreciated that both the quality and quantity of seston available to mussels vary both on tidal and seasonal timescales, and are major factors influencing growth rate (Widdows et al., 1979; Kiørboe and Møhlenberg, 1981; Shumway et al., 1985; Bayne et al., 1987, 1989; 1993; Lucas et al., 1987; Newell et al., 1989; Hawkins and Bayne, 1991; Navarro et al., 1991; for reviews, see Hawkins and Bayne, 1992; Newell and Shumway, 1993). Results are presented here from laboratorybased experiments in which we investigated short-term responses to changes in the amount and composition of suspended seston under defined dietary conditions. Working with large quantities of cultured algae, these experiments have extended the ranges of dietary quantity and quality well beyond those limits over which feeding and growth have been monitored before. This paper highlights the importance of acclimatory processes, and establishes dietary conditions for maximal growth in mussels. Other elements of this research programme, in which we monitored responses in feeding behaviour to natural tidal variations in food availability, and integrate all findings to establish functional interrelations that facilitate the modelling of growth, are reported elsewhere (Hawkins et al., 1996).

\section{MATERIALS AND METHODS}

\section{Collection and acclimation}

On each of two separate experimental periods during September 1991 and September 1992, Mytilus edulis of $50+2 \mathrm{~mm}$ were collected from Boyardville on the Isle d'Oléron. Mussels were immediately cleared of epibiotic growth, and transferred to a large $\left(>100 \mathrm{~m}^{3}\right)$ outdoor pool at the IFREMER hatchery, La Tremblade, France. The water within this pool was replaced daily with natural seawater from the Bay of MarennesOléron, and although there was significant settlement of silt from this seawater, it was enriched with natural blooms of the diatom (alga) Skeletonema costatum. After $14 \mathrm{~d}$ acclimation in September 1991 and $3 \mathrm{~d}$ acclimation in September 1992, physiological measurements were made in acclimated mussels, as well as in mussels from each of three other conditions in which the quantity and/or quality of seston was manipulated through the variable addition of natural silt or algae. Dietary characteristics of these conditions are summarised within Table 1.

\section{Physiological measurements}

Physiological responses were measured in each of 10 individual mussels per condition in September 1991, and in each of 5 individual mussels per condition in September 1992. Each mussel was maintained in a separate plastic tray supplied with seawater at rates of 150 to $200 \mathrm{ml} \mathrm{min}{ }^{-1}$. These rates were sufficient to ensure that volumes of suspended particles determined using a Coulter Multisizer were not reduced by more than $20 \%$ between the inflow and outflow from each mussel tray. Seawater temperatures during both acclimation and experimentation averaged $23.5 \pm 1.0^{\circ} \mathrm{C}$ in September 1991 and $22.0 \pm 1.0^{\circ} \mathrm{C}$ in September 1992. For each mussel, a glass cover-slip was positioned on a ball of putty (Futex) so as to 
Table 1. - Summary of dietary characteristics for each experimental period. Data are the mean \pm 2 SE of at least 3 replicate determinations per feeding condition.

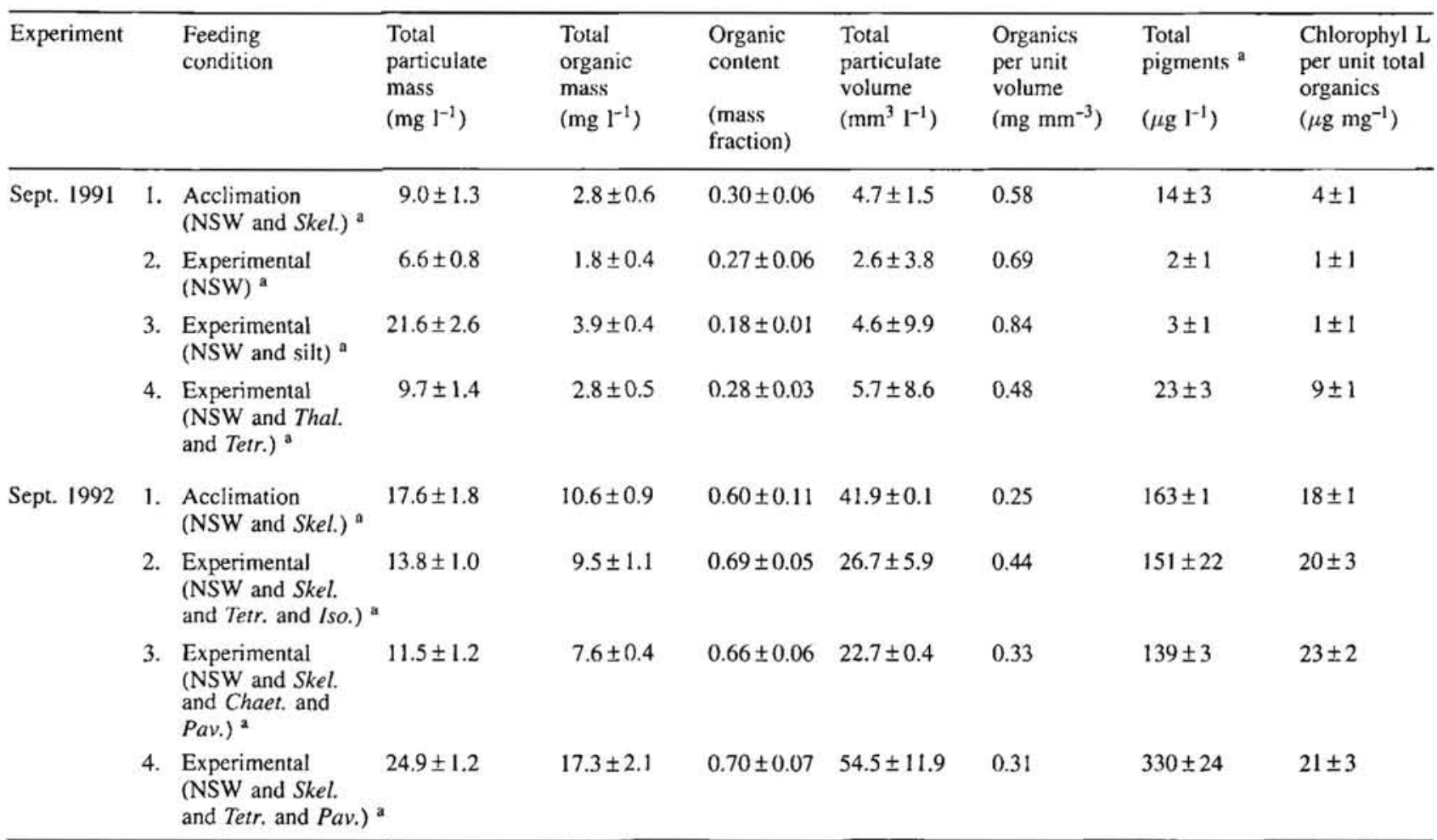

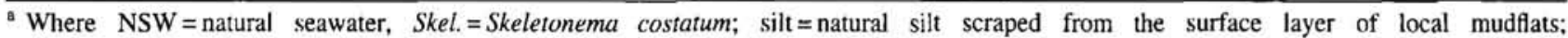
Thal. $=$ Thalassiosira pseudonana $;$ Tetra.$=$ Tetraselmis suecica $;$ Iso. =Isochrysis galbana; Chaet. = Chaetoceros calcitrans; and Pav. = Pavlova lutheri.

b Where total pigments $=$ chlorophyll plus phaeophytin.

separate the true faeces from material that was rejected as pseudofaeces prior to ingestion. Within $24 \mathrm{~h}$ of transferring mussels from the acclimation raceway to the experimental trays, samples of suspended particles from the outflow of empty "control" trays, as well as all true faeces and all pseudofaeces from each individual mussel, were collected separately over at least three intervals of 3 to 4 hours. The total volume of particles $>3 \mu \mathrm{m}$ diameter $\left(\mathrm{mm}^{3} \mathrm{ml}^{-1}\right)$ was measured in outflow seawater samples using a Coulter Multisizer. Faecal samples were homogenised by rapid repeat-pipetting within a standard volume $(22 \mathrm{ml})$ of membrane-filtered $(0.45 \mu \mathrm{m})$ seawater, and two replicate aliquots both of seawater and faecal samples were filtered onto separate pre-weighed and ashed Whatman GFC filters. One of these replicate filters was immediately frozen, for later determination of chlorophyll $a$ content following standard procedures for acetone extraction and fluorometric analysis (Holm-Hansen et al., 1965). The other replicate filter was rinsed with distilled water, dried at $60^{\circ} \mathrm{C}$ before re-weighing to allow calculation of the total dry sample weight per filter, and then ashed at $450^{\circ} \mathrm{C}$ for $4 \mathrm{~h}$ prior to final weighing, allowing further calculation both of the ash (inorganic) and ash-free (organic) masses of each filtered sample.

Food abundance was defined in terms of total particulate mass (TPM; $\mathrm{mg} \mathrm{l}^{-1}$ ) and total particulate volume (TPV; $\left.\mathrm{mm}^{3} \mathrm{I}^{-1}\right)$, and dietary quality defined in terms of the fraction of organic mass (OC; fraction) and the organic mass per unit volume of total seston $\left(O V ; \mathrm{mg} \mathrm{mm}^{-3}\right)$.

Separate components of feeding behaviour were computed according to Hawkins et al. (1996) as described in Table 2 . The present measure of clearance rate $(C R)$ is based upon faecal deposition according to Hawkins et al. (1996) (Table 2), rather than the more traditional method (cf. Bayne et al., 1985) of comparing particle counts within the inflow and outflow from each experimental tray. Previous comparison has established that these different techniques indicate similar differences between the $C R$ of mussels feeding under different conditions $\left(r^{2}=95 \%, n=8\right.$; Hawkins and Smith, unpublished data). $C R$ is a highly variable process, over even a few minutes (Hawkins, unpublished data). Therefore, we chose the current approach as it provides an integrated average measure on the basis of faeces 
Table 2. - Definitions and descriptions of the calculation of separate components of feeding behaviour.

\begin{tabular}{|c|c|c|c|}
\hline Parameter & Acronym & Units & Calculation \\
\hline $\begin{array}{l}\text { Net organic selection } \\
\text { efficiency }\end{array}$ & NOSE & fraction & $\begin{array}{l}\text { [1-(organic fraction within pseudofaeces) : (organic fraction within total } \\
\text { particulates } \\
\text { available in seawater)] }\end{array}$ \\
\hline Net organic absorption rate & NOAR & $\mathrm{mg} \mathrm{h}{ }^{\prime}$ & [NOIR-((mg total true facces egested $\left.\mathrm{h}^{\prime}\right) \times$ (organic fraction within true faeces $\left.\left.)\right)\right]$ \\
\hline $\begin{array}{l}\text { Net absorption efficiency } \\
\text { from ingested organics }\end{array}$ & NAEIO & fraction & {$[N O A R \div N O I R]$} \\
\hline
\end{tabular}

deposited over several hours, rather than the average of several instantaneous measures that are obtained by comparing particle concentrations within the inflow and outflow from an experimental tray. Note also the separate definitions of $C R$ and filtration rate $(F R)$ here (Table 2 ). These terms have often been used synonymously in past studies. However, here and elsewhere, we now prefer to be more explicit, such that $C R$ represents the volume of scawater that is cleared of particles $\mathrm{h}^{-1}$, whereas $F R$ represents the mass of particles filtered $\mathrm{h}^{-1}$ (Hawkins et al., 1996; Iglesias et al., 1996).

Within 8 hours of sampling food and faeces, energy expenditure was measured indirectly as oxygen uptake in the same individual mussels according to Widdows (1985).

Following all determinations of oxygen uptake, the soft tissues were excised from each mussel, dried at $60^{\circ} \mathrm{C}$, and weighed. There were large differences between the body size of individual mussels, which averaged ( \pm 2 SE) $0.74 \pm 0.18 \mathrm{~g}$ dry soft tissue weight for all experimental animals. To account for those differences, physiological responses were standardised to those for an equivalent mussel of $1 \mathrm{~g}$ dry soft tissue weight as follows:

$$
Y_{S}=\left(W_{s} / W_{r}\right)^{b} Y_{t},
$$

where $Y_{s}$ is the standardised parameter, $W_{s}$ is the standard weight $(1 \mathrm{~g}), W_{e}$ is the weight of the experimental animal, $Y_{t}$ is the uncorrected parameter, and $b$ is the corresponding weight exponent of 0.67 for feeding processes (Hawkins et al., 1990) and 0.75 for oxygen consumption (Hawkins and Baync, 1992) in Mytilus edulis. Net energy balance (NEB; $\mathrm{J} \mathrm{h}^{1} \mathrm{~g}^{1}$ dry soft tissue weight) was calculated as follows:

$$
N E B=A-(R),
$$

where $A$ is absorption, and $R$ is metabolic energy expenditure. The calculation of $A$ and $R$, each expressed as $\mathrm{J} \mathrm{h}^{-1} \mathrm{~g}^{-1}$ dry soft tissue weight, was as follows:

$A=$ net organic absorption rate (NOAR; mg per hour $\mathrm{g}^{1}$ dry soft tissue weight $) \times 23.5^{a}\left(\mathrm{~J} \mathrm{mg}^{-1}\right.$ absorbed organics); and

$R$ = oxygen consumption $\left(R ; \mathrm{ml} \mathrm{O}_{2} \mathrm{~h}^{-1} \mathrm{~g}^{-1}\right.$ dry soft tissue weight $) \times 20.33^{h}\left(\mathrm{~J} \mathrm{ml}^{-1} \mathrm{O}_{2}\right)$.

Energy conversion factors $a$ and $b$ were from Widdows et al. (1979) and Bayne et al. (1985), respectively.

Comparisons of statistical difference ( $l$-tests), correlations (Spearman rank and Pearson) and leastsquares curve-fitting used in the analyses and presentation of data were undertaken using SYSTAT for Windows, Version 5 (SYSTAT Inc., Evanston, Illinois, USA).

\section{RESULTS}

\section{September 1991}

Total particulates varied from $6.6 \mathrm{mg} \mathrm{t}^{-1}$ in natural seawater alone (Condition 2), to $21.6 \mathrm{mg} \mathrm{l}^{-1}$ in natural seawater enriched with silt (Condition 3) (Table 1). Alternatively, percentage organic contents of about $30 \%$ were similar in Conditions 1,2 and 4 , but were significantly lower in Condition $3(18.1 \pm 1.3 \%)$. Nevertheless, as for total particulates, total organics remained lowest in the natural seawater of Condition 2 $\left(1.8 \pm 0.4 \mathrm{mg} \mathrm{l}^{-1}\right)$, and highest following the addition of silt in Condition $3\left(3.9 \pm 0.30 \mathrm{mg} \mathrm{l}^{-1}\right)$. Dietary quality measured as $\mathrm{mg}$ organics $\mathrm{mm}^{-3}$ total particulates was also highest in Condition $3(0.84)$, and was lowest following enrichment with algae in Condition 4 (0.48) (Table 1).

Comparing the composition of dietary organics, there were significant differences between each condition in the ratio [( $\mu \mathrm{g}$ chlorophyll $a)$ : (total organics)]. The highest ratios of $4 \pm 1$ and $9 \pm 1$ were 
A. SEPTEMBER 1991
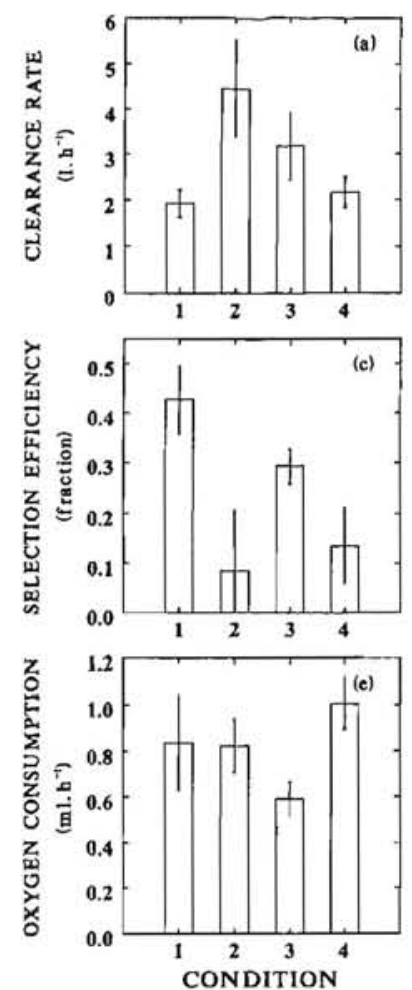
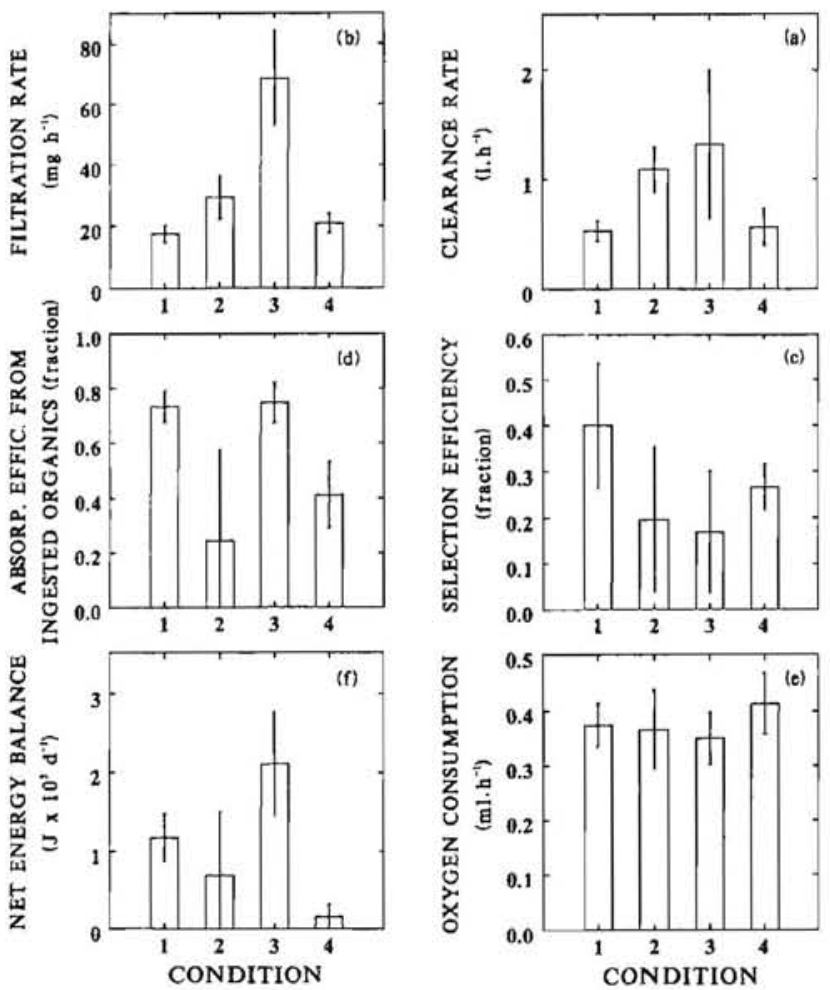

B. SEPTEMBER 1992

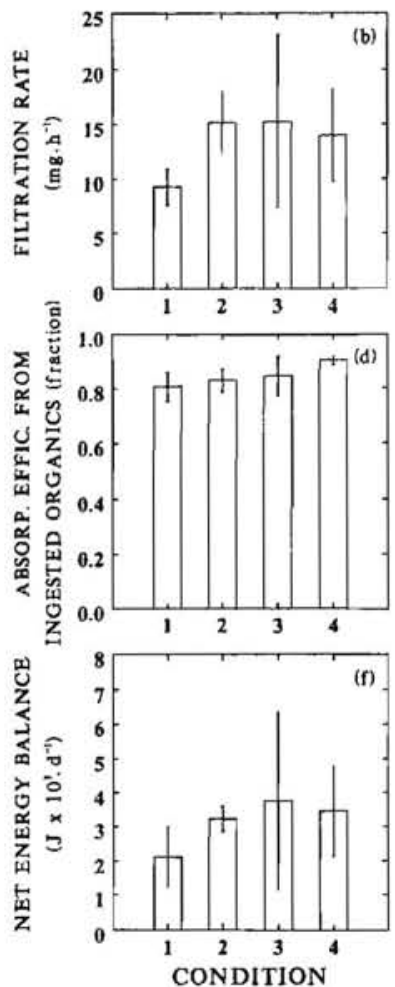

Figure 1. - Clearance rate, filtration rate, net organic selection efficiency, net absorption efficiency from ingested organics, oxygen consumption and net energy balance in Mytilus edulis at each experimental condition during both September 1991 (Fig. 1A: a-f) and September 1992 (Fig. 1B: a-f). Data are the means \pm 2 SE of separate determinations upon 10 replicate individuals during September 1991 and 5 replicate individuals during September 1992. All data are standardised for a mussel of $1 \mathrm{~g}$ dry flesh weight. Experimental conditions are described in Table 1.

seen in Conditions 1 and 4, respectively, reflecting additions of algae (Table 1). Alternatively, the lowest ratios of only $1 \pm 1$ indicate that Conditions 2 and 3 contained the highest proportions of non-living organics (Table 1).

Mean clearance rate $(C R)$, filtration rate $(F R)$, net organic selection efficiency (NOSE), net absorption efficiency from ingested organics (NAEIO), oxygen consumption and net energy balance (NEB) are presented for each dietary condition in Figure 1A: a-f. $C R$ and $F R$ were very significantly elevated among mussels transferred from Condition 1 to both Conditions $2(t=4.6, d f=18, p<0.001$; and $t=2.7$, $d f=18, p=0.03$; respectively) or $3(t=3.1, d f=18$, $p=0.005$; and $t=5.8, d f=18, p<0.001$; respectively), but remained unchanged under Condition $4(p>0.05)$. In contrast, NOSE was highest in mussels acclimated to Condition 1, becoming significantly lower among mussels transferred to Condition $2(t=5.5, d f=18$, $p<0.001)$, Condition $3(t=3.2, d f=18, p=0.004)$ or Condition $4(\mathrm{t}=5.8, d f=18, p<0.001)$ (Fig. 1A: $c)$. $N A E I O$ was significantly reduced among mussels transferred from Condition 1 to Condition $2(t=4.8$, $d f=18, p<0.001)$ or Condition $4(t=4.9, d f=18$, $p<0.001$ ) (Fig. 1A: d). Compared with Condition 1, oxygen consumption remained unchanged in mussels transferred to Conditions 2, 3 or $4(p>0.05)$. Relative to mussels acclimated under Condition 1 , net energy balance remained unchanged under Condition 2 $(p>0.05)$, but was significantly increased $(t=2.4$, $d f=18, p=0.022$ ) under Condition 3 , in which natural seawater had been enriched with silt (Table 1). Alternatively, the addition of unicellular algae to natural seawater under Condition 4 resulted in a significant reduction $(t=5.5, d f=18, p<0.001)$ in net energy balance (Fig. 1A: $f$ ).

\section{September 1992}

Concentrations of total particulate mass in each dietary condition were similar to those during September 1991 (11.5 to $24.9 \mathrm{mg} \mathrm{l}^{-1}$, compared with 6.6 to $21.6 \mathrm{mg} \mathrm{l}^{-1}$, respectively) (Table 1). But as was intended, organic contents $(O C \mathrm{~s})$ were very much higher than during September 1991 (60 to 70\%, compared with 18 to $30 \%$, respectively). Because algae represented a greater fraction of the seston, total particulate volumes (TPVs) were also very much higher than during September 1991 (22.7 to $54.5 \mathrm{~mm}^{3} \mathrm{I}^{-1}$, compared with 2.6 to $5.7 \mathrm{~mm}^{3} \mathrm{l}^{-1}$, respectively). However, organics per unit volume $(\mathrm{OV})$ were consistently lower $\left(0.25\right.$ to $\left.0.44 \mathrm{mg} \mathrm{mm}^{-3}\right)$ 
than in September 1991 (0.48 to $\left.0.84 \mathrm{mg} \mathrm{mm}^{-3}\right)$. For September 1992 alone, all 4 conditions were similar in terms of $O C$ and $\mu \mathrm{g}$ chlorophyll $\mathrm{mg}^{-1}$ total organics, but $T P M$ and $T P V$ were significantly greater in Condition $4\left(24.9 \mathrm{mg} \mathrm{l}^{-1}\right.$ and $\left.54.5 \mathrm{~mm}^{3} \mathrm{l}^{-1}\right)$ than in Conditions 1, 2 and 3 (11.5 to $17.6 \mathrm{mg} \mathrm{l}^{-1}$ and 22.7 to $41.9 \mathrm{~mm}^{3} \mathrm{1}^{-1}$ ) (Table 1).

Physiological responses to each dietary condition are summarised in Figure 1B: a-f. Compared with mussels acclimated to Condition 1, and although only statistically significant for Condition $2(t=2.3$, $d f=8, p=0.048$ ), mean NEBs werc consistently higher under each of the three experimental conditions in which natural seawater had been enriched with cultured algae (Table 1) (Fig. 1B: f). Rates of energy expenditure measured indirectly as oxygen consumption were similar between all 4 conditions $(p>0.05)$ (Fig. 1B: e). Thus, compared with mussels acclimated to Condition 1, the trend for consistently greater mean $N E B$ s in Conditions 2, 3 and 4 resulted primarily from faster rates of energy acquisition. The total organic mass available as seston, NOSE and NAEIO were similar under Conditions 1,2 and $3(p>0.05)$ (Table 1) (Fig. 1B: c, d). Therefore, the trend for greater mean NEBs under Conditions 2 and 3 resulted primarily from faster $C R \mathrm{~s}(t=5.1$, $d f=8, p=0.001 ; t=2.3, d f=8, p=0.049$; respectively) (Fig. 1B: a). Alternatively, relative to Condition 1, $C R$ remained similar under Condition $4 \quad(p>0.05)$ (Fig. 1B: a). The result was that $F R$ remained similar in all three experimental conditions (Fig. 1B: b), and the high $N E B$ under Condition 4 resulted mainly from greater availability of suspended organic matter (Table 1). No other feeding process changed in such a way as to influence $N E B$ under Condition 4 (Fig. 1B: a-f).

\section{Combined data}

Combining data from both September 1991 and September 1992, there was a significant negative correlation between the average $O C$ and $O V$ for all conditions combined $\left(r^{2}=0.73\right.$, residual $d f=6$, $p=0.006$ ). In addition, Spearman rank correlation indicated that $N E B\left(\mathrm{~J} \mathrm{~d}^{-1}\right)$ was positively correlated with both TPM $\left(r_{s}=0.61, n=45, p<0.001\right)$ and $O C$ $\left(r_{s}=0.32, n=45, p<0.05\right)$. As illustrated in Figure 2, data do not allow definitive resolution of the exact forms of these relations with $N E B$. Further, no standard equation described the simultaneous effects of TPM and $O C$ on $N E B$. However, Figure 2 shows how $N E B$ increased with $T P M$ in mussels feeding upon seston with a low $O C$ of up to 0.30 . But when feeding upon seston with $O C$ s from 0.30 to 0.70 , $N E B$ reached an average $( \pm 2 \mathrm{SE}, n=15)$ maximum of $3477 \pm 908 \mathrm{~J} \mathrm{~d}^{-1}$ at TPMs of more than $10 \mathrm{mg} \mathrm{l}^{-1}$, and was not improved with further increases in food availability (Fig. 2). This indicates that mussel growth had reached maximal rates. There were no significant relations between $N E B$ and $O V(p>0.05)$.

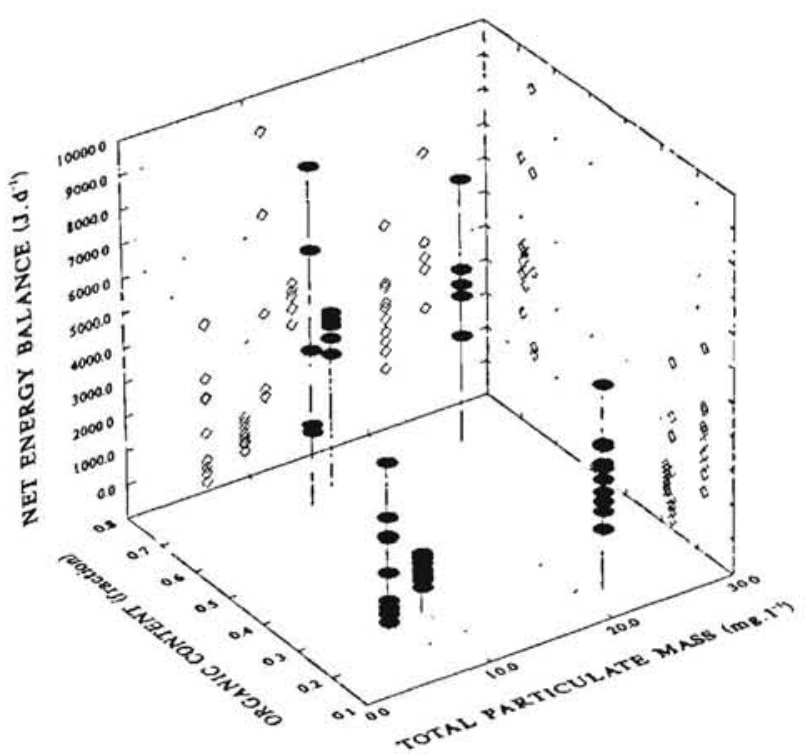

Figure 2. - Short-term responses in net energy balance $(N E B)$ to both the total particulate mass (TPM) and the organic content (OC) of seston available to Mytilus edulis during both September 1991 and Septemher 1992. All data are standardised to $1 \mathrm{~g}$ dry flesh weight. Open diamonds represent two-dimensional data, and solid discs three-dimensional data.

Considering all data from both September 1991 and September 1992, net organic ingestion rate (NOIR) reached an essentially constant level that averaged $( \pm 2 \mathrm{SE}, n=25) 6.48 \pm 1.18 \mathrm{mg}$ organic matter $\mathrm{h}^{-1}$ at all food concentrations above $9.7 \mathrm{mg} \mathrm{l}^{-1}$. Such constancy occurred despite $O C$ more than doubling as TPM increased from 9.7 to $24.9 \mathrm{mg} \mathrm{l}^{-1}$, and was achieved by changes in $C R$. Figure 3 shows how $C R\left(\mathrm{I} \mathrm{h}^{-1}\right)$ decreased rapidly as the availability of suspended particulate organic matter $\left(P O M ; \mathrm{mg} \mathrm{l}^{-1}\right)$ increased, according to a negative relation that was best described by the equation:

$$
\begin{array}{cc}
C R=a P O M^{b} & \\
a=6.67 & {[5.08,8.75]} \\
b=-0.81 & {[ \pm 0.17]}
\end{array}
$$

where $r^{2}=0.70$, residual $d f=43, p<0.001$, and bracketed values indicate $95 \%$ confidence limits. Therefore, compensatory changes in $C R$ acted to help regulate feeding rate, this regulation being associated with the intake of organic matter, rather than of all filtered particles.

\section{DISCUSSION}

In comparing net energy balances $(N E B)$ between dietary conditions during September 1991, there were two differences of note. Firstly, $N E B$ was greater under Condition 3, in which mussels were feeding solely upon their natural diet of suspended silt, 


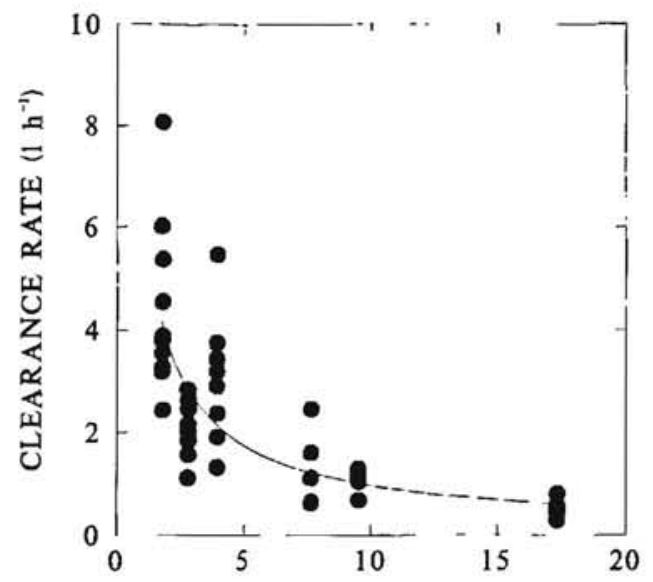

PARTICULATE ORGANIC MATTER (mg.1 ')

Figure 3. - Shont-term responses in clearance rate to particulate organic matter (POM) within seston available to Mytilus edulis during both September 1991 and September 1992. All data are standardised to $1 \mathrm{~g}$ dry flesh weight. The line was fitted by least squares (refer text for equation).

than under Condition 1, in which mussels had been acclimated whilst feeding on a mixture of Skeletonema costatum and silt. This increase in $N E B$ occured despite similar availability of seston in terms of total particulate volume. Further, Condition 3 possessed the lowest fractional contribution of organic mass to total dry particulate weight $(O C)(0.18 \pm 0.01)$. However, it has previously been reported that mussel growth may be stimulated by the addition of silt to available food (Winter, 1976; Kiørboe et al., 1980, 1981; Bayne et al., 1987). Then, it was suggested that enhanced growth stemmed from volumetric constraints that are inherent to digestion, for relative to most phytoplankton or detritus, the nonrefractory organic matter carried by silt represents a greater fraction of total particle volume (Bayne et al., 1987). Our data support this suggestion, for the mass of organics per unit total seston volume $(O V)$ was higher for Condition $3(0.84)$ than in any other dietary condition from both experiments. There was also a significant negative correlation between the average $O C$ and $O V$ for all conditions combined.

We have confirmed earlier findings that mussels preferentially reject inorganic matter as pseudofaeces (Kiørboe et al., 1980, 1981; Prins et al., 1991; Bayne et al., 1993; Hawkins et al., 1996), such that the OC of particles ingested during September 1991 under Condition 3 was enriched by as much as $30 \%$ over and above the $O C$ of natural silt that had been filtered from the water column. The average NOSE of $29 \%$ that we recorded under Condition 3 was at least double that seen under either Condition $2(8 \%)$ or Condition 3 $(13 \%)$. These differences indicate that NOSE may represent an additional physiological basis whereby $N E B$ is higher in mussels feeding upon natural seston, than upon artificial diets that are enriched with algal monocultures. This is consistent with other recent findings showing that the efficiency of pre-ingestive selection may vary according to dietary composition (Iglesias et al., 1992; Bayne et al., 1993; Barillé and Prou, 1994; Hawkins et al., 1996), and which collectively suggest that such selection will be most efficient for suspensions that are composed of mixtures of both relatively inorganic and relatively organic particles, and less efficient for purer suspensions that are composed of particles of relatively similar organic content.

The second notable difference between $N E B$ s during September 1991 was that, compared with mussels acclimated to Condition $1, N E B$ was reduced in Condition 4 , in which mussels were feeding upon seston enriched with algal monoculture. This reduction in $N E B$ occurred despite a similar availability of seston in terms of both mass and volume, similar $C R \mathrm{~s}$, and similar oxygen consumption. Instead, reduced $N E B$ under Condition 4 stemmed mainly from reductions in NOSE and in the net absorption efficiency from ingested organics (NAEIO), which were both significantly lower than in mussels acclimated over the previous 2 weeks under Condition 1. Therefore, within the experimental period of up to 24 hours following initial exposure to Condition 4, mussels were not able to utilise fully the organic matter in laboratory-reared algae that had been used to help create that dietary condition.

As in September 1991, NOSE during September 1992 was also highest in mussels that had previously been maintained under Condition 1. Comparisons between Condition 1 and other experimental conditions during both September 1991 and September 1992 thus suggest that mussels were able to acclimate processes affecting both NAEIO and NOSE. This is consistent with previous reports that, over periods of time exceeding a minimum of $2 \mathrm{~d}$, mussels may adjust other aspects of feeding, including both palp morphology (Essink et al., 1989; Mettam, 1993) and the activity of digestive enzymes (Hawkins and Bayne, 1992). Such adjustments will influence maximal growth, for until they have been effected, $N E B$ may remain independent of dietary improvements over the conditions of any preceding acclimation. This means that the extent by which growth of Mytilus edulis and other animals can be stimulated in the short-term must be influenced by prior nutritional history, just as it is also known to depend upon reproductive status (Hawkins and Bayne, 1992).

The average $N E B$ of $3477 \mathrm{~J} \mathrm{~g}^{-1}$ dry soft tissue $\mathrm{d}^{-1}$ in Mytilus edulis feeding upon Conditions 2, 3 and 4 of September 1992 represents much the highest energy balance documented for any adult mussel (Thompson and Bayne, 1974; Bayne, 1976; Bayne et al., 1989, 1993). Mussel tissue has an energy content of about $23.5 \mathrm{~J} \mathrm{mg}^{-1}$ (Slobodkin and Richman, 1961 ), so that this net energy balance represents a net whole-animal energy gain (=growth) of $14.8 \%$ dry soft tissue $\mathrm{d}^{-1}$ for a standard M. edulis of $1 \mathrm{~g}$ dry 
soft tissue. Exceptionally fast growth should not be unduly suprising, for mussels were ingesting algal organics at an associated average $( \pm 2 \mathrm{SE}, n=15)$ of as much as $20.6 \pm 4.8 \%$ of the whole mussel soft organic tissue weight $\mathrm{d}^{-1}$. Further, although growth generally declines with age, comparable growth has been observed in spat or juveniles of other bivalve species maintained on laboratory diets, including $14 \%$ $\mathrm{d}^{-1}$ for the oyster Ostrea edulis (Laing and Millican 1986), $7.6 \% \mathrm{~d}^{-1}$ for the clam Mercenaria mercenaria (Urban and Pruder, 1992) and $11 \% \mathrm{~d}^{-1}$ for the clam Tapes phillipinarum (Coutteau et al., 1994).

Nevertheless, the maximal rate of growth that has been recorded for Mytilus edulis whilst cultured in the natural intertidal zone of the Bay of MarennesOléron is only about $2 \% \mathrm{~d}^{-1}$ for a standard mussel of $1 \mathrm{~g}$ dry flesh weight (Hawkins et al., 1996; calculated from Boromthanarat and Deslous-Paoli, 1988). Admittedly, mussels in the intertidal zone may grow slower than when fed continuously in the laboratory. However, our maximal measured growth of $14.8 \%$ dry soft tissue $\mathrm{d}^{-1}$ under experimental laboratory conditions is much higher than could be explained on that basis alone. We suggest three reasons for our high measured growth rates. Firstly, high rates of organic ingestion as have been observed here do not occur under normal circumstances in the natural environment. Natural concentrations of chlorophyll and other suspended organic matter never reach levels that were available in the present experimental study (e.g. Karlson et al., 1996). Secondly, mussels in the present study always filtered fresh (food-rich) seawater. But in the natural environment, mussels and other benthic filter-feeders may deplete the concentration of available particles through multiplefiltration of water within the benthic boundary layer, thereby adding to further food-limitation of growth (e.g. Fréchette et al., 1989; Butman et al., 1994). And thirdly, our fast growth rates may reflect the high energy content of organics that were available within our experimental diets. Because those experimental diets were heavily enriched with cultured algae, we have assumed that the energy content of particulate organic matter was $23.5 \mathrm{~J} \mathrm{mg}^{-1}$, according to Widdows et al. (1979), and which is a typical energy value for most organisms (Slobodkin and Richman, 1961). Such high energy contents may sometimes occur within natural algal blooms. However, they are not normally present in sediment-rich waters such as of the Bay of Marennes-Oléron, where the energy available as food material in proteins, lipids and carbohydrates may be less than $10 \mathrm{~J} \mathrm{mg}^{-1}$ particulate organic matter (Héral et al., 1983). Interestingly, if one recalculates $N E B$ in M. edulis feeding upon Conditions 2, 3 and 4 of September 1992 assuming (i) the same rates of organic absorption and oxygen consumption as were recorded here, and (ii) $7.25 \mathrm{~J} \mathrm{mg}^{-1}$ available/absorbed organic matter as measured in the Bay of Marennes-Oléron by Héral et al. (1983) during May, when growth of mussel tissue was fastest (Boromthanarat and Deslous-Paoli, $1988)$, the resulting average ( \pm 2 SE) of $946 \pm 101 \mathrm{~J} \mathrm{~g}^{-1}$ dry soft tissue $\mathrm{d}^{-1}$ represents only $4.0 \%$ dry soft tissue $\mathrm{d}^{-1}$ for a standard $M$. edulis of $1 \mathrm{~g}$ dry soft tissue. This is obviously much more consistent with growth observed in the natural environment (Boromthanarat and Deslous-Paoli, 1988; Hawkins et al., 1996; and refer above).

Clearly, the present experimental conditions when mussels were fed ad libitum with seston that was heavily enriched with cultured algae were not of normal environmental relevance. Nevertheless, our findings help to understand dietary constraints upon the growth of filter-feeding bivalves. This is of particular interest in the Marennes-Oléron, where there are signs that food may be limiting oyster production (Héral, 1993), and where commercially-reared oysters (Crassostrea gigas) are conditioned in enclosed ponds (claires) whilst feeding upon blooms of algae over several weeks prior to sale. We have shown that NOIR in mussels feeding upon seston with an average $O C$ of more than $60 \%$ reached a general maximum at TPMs of less than $11.5 \mathrm{mg} \mathrm{l}^{-1}$, and was not improved with further increases in food availability, associated with regulatory reductions in $C R$ that maintained NOIR independent of changes in both TPM and $O C$. The implication is that digestive processes had become saturated when organic ingestion reached about $6.5 \mathrm{mg}$ organics $\mathrm{g}^{-1}$ soft dry mussel tissue $\mathrm{h}^{-1}$ in a standard M. edulis of $1 \mathrm{~g}$ dry soft tissue, and which represented $20.6 \%$ of all soft tissue organic mass mussel-1 $\mathrm{d}^{-1}$. Such saturation of organic ingestion is consistent with previous conclusions based on comparative allometries showing that limitations to growth in Mytilus edulis and other bivalves are associated with the rate of food processing (Hawkins et al., 1990). In turn, the rate of growth that is actually achieved from maximal rates of food processing and absorption will depend upon the composition of absorbed organics, and how those organics match specific nutritional requirements of the organism at that time.

\section{Acknowledgements}

This work was supported by the Commission of the European Communities (contract FAR AQ 2500) and has been presented in the GIP Symposium on: "Relations continent - zones côtières: dynamique des apports et conséquences biologiques, à travers l'exemple de la Charente"; La Rochelle (France) 13-15 September 1994. 


\section{REFERENCES}

Barillé L., J. Prou 1994. Modeling Japanese nyster physiological processes under natural tidal variations in suspended particulate matter. Comm. Meet. Int. Counc. Explor. Sea CM-ICES/F 22, 1-12.

Bayne B. L., D. A. Brown, K. Burns, D. R. Dixon, A. Ivanovici, D. R. Livingstone, D. M. Lowe, M. N. Moore, A. R. D. Stebbing J. Widdows 1985. The effects of stress and pollution on marine animals. Praeger Scientific, New York, $384 \mathrm{p}$.

Bayne B. L., A. J. S. Hawkins, E. Navarro 1987. Fecding and digestion by the common mussel Mytilus edulis L. (Bivalvia: Mollusca) in mixtures of silt and algal cells at low concentrations. J. Exp. Mar. Biol. Ecol. 111, 1-22.

Bayne B. L., A. J. S. Hawkins, E. Navarro, J. I. P. Iglesias 1989. The effects of seston concentration on fecding, digestion and growth in the mussel Mytilus edulis. Mar. Ecol. Prog. Ser. 55, 47-54.

Bayne B. L., J. I. P. Iglesias, A. J. S. Hawkins, E. Navarro, M. Héral, J. M. Deslous-Paoli 1993. Fecding behaviour of the mussel, Mytilus edulis L.; responses to variations in both quantity and organic content of seston. J. Mar. Biol. Assoc. U. K. 73, 813-829.

Boromthanarat S., J.-M. Deslous-Paoli 1988. Population of Mytilus edulis L. reared on bouchots in the Bay of Marennes-Oléron: comparison between two methods of culture. Aquaculture 72, 255-263.

Butman C. A., M. Fréchette, W. R. Geyer, V. R. Starczak 1994. Flume experiments on food supply to the blue mussel Mytilus edulis L. as afunction of boundary-layer flow. Limnol. Oceanogr. 39, 1755-1767.

Coutteau P., K. Curć, P. Sorgeloos 1994. Effect of algal ration on feeding and growth of juvenilc Manila clam Tapes philippinarum (Adams and Reeve). J. Shellfish Res. 13, 47-55.

Deslous-Paoli J.-M., S. Boromthanarat, M. Héral, W. Boromthanarat, D. Razet 1990. Energy budget of a Mytilus edulis L. population during its first ycar on bouchots in the Bay of Marennes-Oléron. Aquaculture 91, 49-63.

Essink K., P. Tydeman, F. de Koning, H. L. Kleef 1989. On the adaptation of the mussel Mytilus edulis L. to different environmental suspended matter concentrations. In: Biochemical and physiological adaptation in marine organisms. R. Z. Klekowski, E. Styczynska-Jurewicz, L. Falkowski eds. 21 st Europ. Mar. Biol. Symp., Ossolineum, Gdansk, 41-51.

Fréchette M., C. A. Butman, R. W. Geyer 1989. The importance of boundary-layer flows in supplying phytoplankton to the benthic suspension feeder, Mytilus edulis L. Limnol. Oceanogr. 34, 19-36.

Hawkins A. J. S., B. L. Bayne 1991. Nutrition of marine mussels: factors influencing the relative utilizations of protein and energy. Aquaculture 94, 177-196.

Hawkins A. J. S., B. L. Bayne 1992. Physiological processes, and the regulation of production. In: The mussel Mytilus: ecology, physiology, genetics and culture. E. Gosling ed. Elsevier Science Publishers B. V., Amsterdam, 171-222.

Hawkins A. J. S., R. F. M. Smith, B. L. Bayne, M. Héral 1996. Novel observations underlying fast growth of suspension-feeding shellfish in turbid environments: Mytilus edulis. Mar. Ecol. Prog. Ser. 131, 179-190.

Héral M. 1993. Why carrying capacity models are useful tools for management of bivalve molluscs culture. In:
Bivalve filter fecders in estuarinc and coastal ecosystem processes. R. F. Dame ed. Springer-Verlag, Berlin, 455-478.

Héral M., J.-M. Deslous-Paoli, J. M. Sornin 1983. Transferts énergétiques entre l'huître Crassostrea gigas ct la nourriture potentielle disponible dans un bassin ostréicole: premières approches. Oceanis 9, 169-194.

Holm-Hansen O., C. J. Lorenzen, R. W. Holmes, J, D. H. Strickland 1965. Fluorometric determination of chlorophyll. J. Cons. Int. Explor. Mer 30, 3-15.

Iglesias J. I. P., E. Navarro, P. Alvarez. Jorna, I. Armentia 1992. Feeding, particle selection and absorption in cockles Cerastoderma edule (L.) exposed to variable conditions of food concentration and quality. J. Exp. Mar. Biol. Ecol. 162, 177-198.

Iglesias J. I. P., M. B. Urrutia, E. Navarro, P. Alvarez-Jorna, X. Larretxea, S. Bougrier, M. Héral 1996. Variability of feeding proccsses in the cockle Cerastoderma edule (L.) in response to changes in seston concentration and composition. J. Exp. Mar. Biol. Ecol. 197, 121-143.

Karlson B., L. Elder, W. Granéli, E. Sahlsten, M. Kuylenstierna 1996. Subsurface chlorophyll maxima in the Skagerrak-processes and plankton community structure. J. Sea Res. 35, 139-158.

Kiørboe T., F. Møhlenberg 1981. Particle selection in suspension-feeding bivalves. Mar. Ecol. Prog. Ser. 5, 291-296.

Kiørboe T., F. Møhlenberg, O. Nøhr 1980. Feeding, particle selection and carbon absorption in Mytilus edulis in different mixtures of algae and resuspended bottom matcrial. Ophelia 19, 193-205.

Kiørboe T., F. Møhlenberg, O. Nøhr 1981. Effect of suspended bottom material on growth and energetics in Mytilus edulis. Mar. Biol. 61, 283-288.

Laing I., P. F. Millican 1986. Relative growth and growth cfficiency of Ostrea edulis L. spat fed various algal diets. Aquaculture 54, 245-262.

Lucas M. I., R. C. Newell, S. E. Shumway, L. J. Seiderer, R. Bally 1987. Particle clearance and yield in relation to bacterioplankton and suspended particulate availability in estuarine and open coast populations of the mussel Mytilus edulis. Mar. Ecol. Prog. Ser. 36, 215-224.

Mettam C. 1993. Changing palp morphology of Mytilus edulis along a gradient of turbidity. In: Quantified phenotypic responses in morphology and physiology. J. C. Aldrich ed. $27^{\text {th }}$ European Marine Biology Symposium, Dublin, Ireland, 229-237.

Navarro E., J. I. P. Iglesias, A. Perez Camacho, U. Labarta, R. Berias 1991. The physiological energetics of mussels (Mytilus galloprovincialis Lmk.) from different cultivation rafts in the Ria de Arosa (Galicia, N. W. Spain). Aquaculture 94, 197-212.

Newell C. R., S. E. Shumway 1993. Grazing of natural particulates by bivalve molluscs: a spatial and temporal perspective. In: Bivalve filter feeders in estuarine and coastal ecosystem processes. R. F. Damc ed. SpringerVerlag, Bcrlin, 85-148.

Newell C. R., S. E. Shumway, T. L. Cucci, R. Selvin 1989. The effects of natural seston particle size and type on feeding rates, feeding selectivity and food resource availability for the mussel Mytilus edulis Linnaeus, 1758 at bottom culture sites in Maine. J. Shellfish Res. 8, 187-196. 
Prins T. C., A. C. Smaal, A. J. Pouwer 1991. Selective ingestion of phytoplankton by the bivalves Mytilus edulis L. and Cerastoderma edule (L.). Hydrobiol. Bull. 25, 93-100.

Shumway S. E., T. L. Cucci, R. C. Newell, T. M. Yentsch 1985. Particle selection, ingestion and absorption in filtcrfecding bivalves. J. Exp. Mar. Biol. Ecol. 91, 77-92.

Slobodkin L. B., S. Richman 1961. Calories/gm in species of animals. Nature 191, 299.

Smaal A. C., J. H. G. Verhagen, J. Coosen, H. A. Haas 1986. Interaction between seston quantity and quality and bonthic suspension fecders in the Oosterschelde. The Netherlands. Ophelia 25, 385-399.

Thompson R. J., B. L. Bayne 1974. Some relationships between growth, metabolism and food in the mussel Mytilus edulis. Mar. Biol. 27, 317-326.
Urban E. R., G. D. Pruder 1992. A method of economic comparisons for aquaculture diet development. Aquaculture 5), 127-142.

Widdows J. 1985. Physiological measurements. In: The effects of stress and pollution on marine animals. B. L. Bayne et al. ed. Praeger Scientific, New York, 3-45.

Widdows J., P. Fieth, C. M. Worrall 1979. Relationships between seston, avaitable food and feeding activity in the common mussel Mytilus edulis. Mar. Biol. 55, 195-207.

Winter J. E. 1976. Feeding experiments with Mytilus edulis L. at small laboratory scale. II. The influence of suspended silt in addition to algal suspensions on growth. In: Research in mariculture at laboratory-and pilot-scale. G. Persoone, E. Jaspers eds. Vol. 1. 10th Europ. Mar. Biol. Symp., Universa Press, Wetteren, 583-600. 